\title{
Wpływy Narodowej Demokracji w województwie białostockim. Elity i ich rola w tworzeniu politycznych struktur endeckich (1919-1939)
}

\section{Uwagi wstępne}

Badania historyczne nad polskimi elitami politycznymi, przywódcami formacji politycznych, mają bogatą historiografię. Także i dorobek naukowy badaczy dotyczący elit endeckich znalazł odzwierciedlenie w licznych opublikowanych studiach, stanowiących wynik wieloletnich badań, intensywnie prowadzonych zwłaszcza od lat osiemdziesiątych XX w. Zagadnienie to opracowywano w ujęciach biograficznych dotyczących głównych twórców ideowopolitycznych tego nurtu (Roman Dmowski, Zygmunt Balicki czy Jan Ludwik Popławski) oraz w pracach opisujących całościowo grupy elit endeckich. Wskazać należy w tym miejscu przede wszystkim studia takich autorów jak Roman Wapiński ${ }^{1}$, Krzysztof Kawalec $^{2}$, Teresa Kulak ${ }^{3}$, Ewa Maj czy Szczepan Wierzchosławski ${ }^{5}$. Wyniki badań wymienionych autorów stanowią niejako punkt wyjścia dla dalszych rozważań nad wpływami środowisk politycznych obozu narodowego na ziemiach polskich zarówno przed pierwszą wojną światową, jak i w okresie II Rzeczypospolitej.

Elity to grupy społeczeństwa cieszące się autorytetem i wysoką w nim pozycją, pełniące szczególną rolę społeczną oraz wyróżniające się działaniami na rzecz środowisk pozostających pod ich wpływem. Dotychczas badacze zajmujący się daną problematyką wskazywali na elity polityczne jako elity władzy, osoby pełniące funkcje kierownicze w organizacjach politycznych, uczestniczące w podejmowaniu decyzji politycznych ${ }^{6}$. Przyjmowano także klasyfikację elit według obecności grup czy jednostek w decyzyjnych centrach politycznych,

\footnotetext{
${ }^{1}$ R. Wapiński, Pokolenia Drugiej Rzeczypospolitej, Wrocław 1991; idem, Endecja na Pomorzu 19201939, Gdańsk 1966.

${ }^{2}$ K. Kawalec, Roman Dmowski, Warszawa 2009.

3 T. Kulak, Jan Ludwik Popławski 1854-1908. Biografia polityczna, t. I-II, Wrocław 1984.

${ }^{4}$ E. Maj, Narodowa Demokracja w województwie lubelskim w latach 1918-1939, Lublin 2002.

${ }_{5}^{5}$ S. Wierzchosławski, Elity polskiego ruchu narodowego w Poznańskiem i w Prusach Zachodnich w latach 1850-1914,Toruń 1992.

${ }^{6}$ U. Hoffman-Lange, Metody badania elit, w: Zachowania polityczne, t. II, red. R. J. Dalton, H. D. Klingemann, tłum. A. Brzóska i in., Warszawa 2010, s. 527.
} 
aktywnego ich udziału w organizacjach politycznych, wpływu na kreowanie rzeczywistości społecznej czy politycznej.

W tym opracowaniu analizie i opisowi poddana zostanie problematyka dotycząca budowania przez Narodową Demokrację wpływów politycznych w województwie białostockim. W oparciu o przykłady wybranych jednostek przedstawiona zostanie charakterystyka elit oraz ich rola w tworzeniu struktur endeckich na omawianym terenie. Opisywani przedstawiciele środowisk przywódczych stanowili grupę niejednolitą pod względem społecznym, zawodowym, wykształcenia, wieku, pełnionych funkcji, oddziaływania politycznego i - co się z tym wiąże - pozycji w środowiskach politycznych, w których funkcjonowali. Znacząca ich większość urodziła się w latach osiemdziesiątych i dziewięćdziesiątych XIX w. Ich pokolenie w znaczącej większości działalność polityczną rozpoczynało przed 1918 r., a w II Rzeczypospolitej kontynuowało ją w różnych formach (przykładowo w parlamencie, w partiach czy organizacjach politycznych). Na początku lat trzydziestych w strukturach politycznych swoje miejsce zaznaczyła młodzież (osoby urodzone pomiędzy 1904/1905 r. a pierwszą wojną światową), jednak w środowiskach przywódczych odgrywała oni rolę drugorzędną. Na drugim planie wśród elit Narodowej Demokracji były także kobiety. Można wskazać zaledwie kilka, które mogłyby być do nich włączone na omawianym terytorium. Przedstawiciele elit związani byli z terytorium poddawanym analizie głównie poprzez więzi rodzinne oraz prowadzoną w województwie działalność polityczną. Elity obozu narodowego w województwie białostockim to częściowo także reprezentanci krajowego aparatu politycznego. Publikowali oni poglądy polityczno-ideowe w książkach, broszurach i na łamach prasy, kierowali formowaniem struktur politycznych (w tym formacji partyjnych) na poziomie regionalnym i lokalnym.

Elity Narodowej Demokracji z obszaru województwa białostockiego to w znaczącej części grupa sformalizowana, przynależna do struktur partyjnych - Związku LudowoNarodowego, Stronnictwa Narodowego, Obozu Wielkiej Polski czy Obozu NarodowoRadykalnego - oraz organizacji współpracujących z partiami, jak przykładowo Narodowa Organizacja Kobiet. W skład elit wchodzili plasujący się na szczycie tzw. drabiny politycznej posłowie czy senatorowie, przedstawiciele politycznych gremiów przywódczych w strukturach ogólnopolskich, także liderzy polityczni z poziomu województwa, powiatu czy miasta (np. przewodniczący czy prezesi partyjnych kół powiatowych oraz przedstawiciele zarządów tych kół). W skład elit wchodzili również oboźni Obozu Wielkiej Polski oraz wydawcy i redaktorzy gazet związanych z narodowym kierunkiem polityczno-ideowym ${ }^{7}$.

$\mathrm{W}$ analizowanym okresie województwo białostockie było terenem złożonym z części odrębnych w czasie zaborów: łomżyńskiego i rejonu suwalsko-augustowskiego (wchodzących w sklad guberni suwalskiej), leżących w granicach byłego Królestwa Polskiego, oraz terytorium dawnej guberni grodzieńskiej, leżącej na obszarze Cesarstwa Rosyjskiego z tzw. obwodem białostockim. W okresie II Rzeczypospolitej województwo białostockie (Białostocczyzna) było obszarem złożonym pod względem etniczno-religijnym. W zachodniej części Białostocczyzny pod względem liczebności dominowała polska ludność katolicka, w okolicach Sejn na Suwalszczyźnie przeważali Litwini, w południowo-wschodniej części województwa większość stanowiła prawosławna ludność białoruska. W miastach, podobnie jak w większości ówczesnych miast ziem polskich, dominowali Żydzi i Polacy, a w Białymstoku i w Grodnie aktywność polityczną zapoczątkowały również elity białoruskie. Ta mozaika narodowościowo-wyznaniowa oraz odczuwalne w omawianym okresie podziały terytorialne z czasu zaborów rzutowały na przyjmowanie przez mieszkańców woje-

\footnotetext{
${ }^{7}$ Por. E. Maj, Elity polityczne Narodowej Demokracji na Lubelszczyźnie w latach 1918-1939, w: Regionalne elity polityczne II i III Rzeczypospolitej, red. M. Dajnowicz, Białystok 2013, s. 175.
} 
wództwa poglądów politycznych oraz aktywność polityczną przejawiającą się we frekwencji wyborczej. Wpływy polityczne poszczególnych nurtów odzwierciedlały także aktywność, znaczenie czy pozycję elit politycznych wśród mieszkańców danego terytorium.

\section{Wpływy Narodowej Demokracji i jej struktury polityczne}

Wybory do Sejmu Ustawodawczego w województwie białostockim odbyły się w 1919 r. w trzech terminach ze względu na etapy wyzwalania Białostocczyzny. Już wówczas zauważalna była szczególna aktywność mieszkańców obszarów postszlacheckich (powiaty wysokomazowiecki, łomżyński ${ }^{8}$, przejawiająca się w wyższej niż na innych obszarach województwa białostockiego frekwencji wyborczej. Niską frekwencję wyborczą odnotowano na terenach zamieszkanych głównie przez ludność białoruską (prawosławną), zamieszkującą południowowschodnią część województwa ${ }^{9}$. Wybory zdecydowanie wygrała szeroko rozumiana prawica (około osiemdziesięcioprocentowe poparcie mieszkańców województwa). W szczególności w wymienianych powiatach wysokomazowieckim, łomżyńskim oraz bielskim poparcie dla bloku Związku Ludowo-Narodowego osiągało wynik zbliżony nawet do 90 proc. $^{10}$

Wyborom do Sejmu Ustawodawczego towarzyszyło ogólne ożywienie mieszkańców związane z radością z powodu odzyskania przez Polskę niepodległości. Na ten temat pisały gazety lokalne, które w tzw. zapowiedziach głównych, umieszczanych najczęściej na pierwszych stronach, zamieszczały apele do czytelników o korzystanie z możliwości udziału w wyborach. Udział Polaków w głosowaniu łączono z koniecznością zaangażowania się ludności w proces tworzenia rzeczywistości społecznej odrodzonego państwa polskiego. Wraz z agitacją na rzecz udziału w wyborach pojawiły się w prasie szczegółowe instrukcje dotyczące przygotowań do głosowania i zaleceń na temat zachowania się podczas aktu wyborczego ${ }^{11}$. Jednocześnie od 1919 r. podjęto działania dotyczące powołania terenowych kół Związku Ludowo-Narodowego. W tworzenie tych placówek zaangażowali się m.in. posłowie Sejmu Ustawodawczego, przykładowo ks. Kazimierz Lutosławski, Jan Załuska (z łomżyńskiego) czy Józef Zmitrowicz $(\mathrm{z} \text { Białegostoku })^{12}$. Proces ten w województwie trwał od wiosny 1919 do końca 1922 r., kiedy struktury partyjne związku we wszystkich powiatach na tym terenie z dominacją ludności polskiej (katolickiej) zostały uformowane. Najbardziej owocny pod tym względem był $1921 \mathrm{r}$., kiedy prowadzono również akcje wyborczo-propagandowe przed wyborami do parlamentu w 1922 r. I tak przykładowo łomżyńskie koło Związku Ludowo-Narodowego formalnie powstało w lutym 1920 r. (z członkostwem kobiet, w tym zasiadających również w zarządzie), w Grodnie w sierpniu 1921 r., w Białymstoku we wrześniu 1921 r., w Sokółce w lutym 1922 r. ${ }^{13}$

\footnotetext{
${ }^{8} \mathrm{~W}$ wymienionych powiatach ludność drobnoszlachecka (postszlachecka) stanowiła większość (powiat wysokomazowiecki) lub znaczący odsetek (powiaty łomżyński, ostrowski) ludności wsi.

${ }^{9}$ Frekwencja wyborcza ,podzieliła” województwo na dwa odmienne pod względem aktywności wyborczej obszary. Na terenach byłego Królestwa Polskiego osiągała nawet 9 proc., natomiast na terenach dawnego tzw. obwodu białostockiego z dominacją Białorusinów wynosiła około 30 proc., w niektórych rejonach zaledwie 5 proc., Statystyka wyborów do Sejmu Ustawodawczego, red. L. Krzywicki, Warszawa 1921, s. 15-59. ${ }^{10}$ Ibidem. Por. J. Milewski, Z dziejów województwa białostockiego w okresie międzywojennym, Białystok 1999, s. 37.

${ }^{11}$ W.O., Wybory. Co każdy obywatel uczynić powinien w dniu wyborów, „Dziennik Białostocki” [dalej: „DzB”], 15 VI 1919, nr 57, s. 1.

12 J. Z. [Józef Zmitrowicz], Praca narodowa, „DzB”, 18 IV 1919, nr 11, s. 1; Wybory w Ziemi Bielskiej, „Dziennik Wileński” [dalej: „DzW”], 19 VI 1919, nr 50, s. 2.

${ }_{13}$ M. Dajnowicz, Działalność polityczna elit Narodowej Demokracji na Bialostocczyźnie w latach 1918-1928, w: Regionalne elity polityczne..., s. 195.
} 
O szeroko zakrojonej agitacji politycznej prowadzonej wśród mieszkańców województwa białostockiego donosiły periodyki regionalne związane z endecją (,Kurier Białostocki”, „Gazeta Łomżyńska”), jak i gazety o zasięgu krajowym („Gazeta Warszawska”). W tej ostatniej dość szczegółowo opisywano działania w okresie wyborczym inspirowane przez Związek LudowoNarodowy, zwłaszcza we zachodniej części województwa ${ }^{14}$. W działalność wyborczą popierającą endecję angażował się kler katolicki, a także kobiety, zwłaszcza działaczki takich organizacji jak Narodowa Organizacja Kobiet, Stowarzyszenie Zjednoczonych Ziemianek, Polski Związek Chrześcijańskiej Służby Domowej, Katolicki Związek Polek czy Koło Polek ${ }^{15}$.

Zjazd członków Związku Ludowo-Narodowego w czerwcu 1922 r. w Białymstoku, w którym uczestniczyło około trzystu osób, relacjonowała „Gazeta Warszawska”. Obrady odbywające się w siedzibie białostockiego „Sokoła” zdominowała tematyka organizacyjnej pracy narodowej przed zbliżającymi się wyborami parlamentarnymi. Informowano uczestników o zasadach ordynacji wyborczej, ostrzegano przed wrogą agitacją stronnictw lewicowych i socjalistów oraz propagandą prożydowską. Wystąpili wówczas z przemowami do uczestników posłowie z Białostocczyzny, którzy parę miesięcy później weszli w skład Sejmu I kadencji, m.in. Stanisław Włodek (łomżyńskie), Michał Arcichowski (z okręgu Bielsk Podlaski), Jan Załuska. Głos zabierali również delegaci powiatowi związku, reprezentujący powiaty wysokomazowiecki, grodzieński, wołkowyski, ostrowski, suwalski. W relacji przedstawiającej wnioski ze zjazdu wskazano na pozytywne efekty tzw. pracy narodowej wśród ludności województwa białostockiego, co było efektem stabilnie działających już w tym czasie struktur Związku Ludowo-Narodowego, zwłaszcza w zachodniej części Białostocczyzny ${ }^{16}$.

W wyborach do parlamentu w listopadzie 1922 r. blok Chrześcijańskiego Związku Jedności Narodowej zdobył największe poparcie na terytorium omawianego województwa. Największy sukces, podobnie jak w poprzednich wyborach, blok narodowy uzyskał w powiatach wysokomazowieckim, ostrowskim i łomżyńskim (siedemdziesięciopięcioprocentowe poparcie w pierwszym $\mathrm{z}$ wymienionych powiatów i pięćdziesięcioczteroprocentowe w ostatnim). Odnotowano także na tych terenach stosunkowo dużą frekwencję wyborczą (od około 70 proc. do blisko 80 proc. $)^{17}$.

Wybory w 1928 r. potwierdziły ustalony wcześniej zasięg wpływów Narodowej Demokracji na obszarze Białostocczyzny. Tzw. polityczną pracę organiczną w zakresie odtworzenia partyjnych struktur narodowych z dużą intensywnością podjęto po przewrocie majowym w $1926 \mathrm{r}^{18}$ Od jesieni 1928 r. rozpoczęto w województwie działania w celu utworzenia struktur Stronnictwa Narodowego, w co zaangażował się głównie Witold Staniszkis oraz — z mniejszą energią — również Jan Załuska. W pracę na rzecz powołania w 1927 r. w województwie placówek Obozu Wielkiej Polski włączył się zwłaszcza poseł Romuald Bielicki oraz członek władz centralnych Obozu Wielkiej Polski Zygmunt Berezowski, a na Suwalszczyźnie - Zygmunt Kadłubowski (poseł z okręgu grodzieńskiego) ${ }^{19}$. Z Zygmuntem Kadłubowskim współpracował Stanisław Zaleski, oboźny Obozu Wielkiej Polski powiatu suwalskiego, organizator wielu akcji agitacyj-

${ }^{14}$ Glos województwa białostockiego, Gazeta Warszawska” [dalej: „GW”], 13 VI 1022, nr 159, s. 3.

15 Odezwa Organizacji Kobiecych, „GW”, 20 VII 1922, nr 196, s. 5; Apel Koła Polek, ibidem, 21 IX 1922, nr 260, s. 3; Wiec Kobiet Polskich, „Gazeta Łomżyńska” [dalej: „GŁ”], 28 X 1922, nr 42, s. 5.

${ }^{16}$ W., Zjazd Zwiazku Ludowo-Narodowego w Biatymstoku, „GW”, 2 VII 1922, nr 178, s. 6.

${ }^{17}$ Na podstawie Statystyki wyborów do Sejmu i Senatu odbytych w dniu 5 I 12 listopada 1922 roku, Warszawa 1926, s. 17-21. Szczegółowe wyliczenia dotyczące wyborów z 1928 r. zob. M. Dajnowicz, Działalność polityczna elit Narodowej Demokracji..., s. 196-200.

${ }_{18}$ Archiwum Państwowe w Białymstoku [dalej: APB], Urząd Wojewódzki Białostocki [dalej: UWB], sygn. $35, \mathrm{k} .7 \mathrm{a}$; sygn. $38, \mathrm{k} .2$ i $\mathrm{n}$.

19 APB, UWB, sygn. 38, k. 25 i n.; sygn. 318, k. 12a. 
nych obozu w powiecie. S. Zalewski podjął się m.in. organizacji komórek młodzieżowych na Suwalszczyźnie, wyznaczał delegatów młodzieży na zjazdy w Warszawie ${ }^{20}$.

Wydaje się także, że jeszcze intensywniej niż około 1922 r. w działalność politycznopropagandową przed wyborami do parlamentu w 1928 r. zaangażował się Kościół katolicki, w tym osobiście ówczesny biskup łomżyński Stanisław Łukomski, który apelował o udział w nich i głosowanie na Listę Katolicko-Narodową, oraz przede wszystkim biskup Romuald Jałbrzykowski, metropolita wileński, którego komunikaty w tej sprawie publikowano na łamach łomżyńskiej prasy ${ }^{21}$. Zabiegano również o głosy kobiet, angażując w sprawy organizacyjne i propagandowe Narodową Organizację Kobiet. Białostocka NOK inicjowała w Białymstoku liczne odczyty i spotkania z działaczkami narodowymi z Warszawy i innych miast Polski, posłankami, takimi jak Ewelina Pepłowska (weszła do Sejmu III kadencji), Zofia Sokolnicka czy senatorka Józefa Szebeko, pierwsza przewodnicząca Narodowej Organizacji Kobiet. Przykładowo, związany z endecją „Kurier Białostocki ABC” donosił, że w lutym 1928 r. w Białymstoku w sali Stowarzyszenia Robotników Chrześcijańskich staraniem tej organizacji odbyło się zebranie przedwyborcze, na którym przemawiała zaproszona przez białostocczanki senatorka Józefa Szebeko. Przypomniała ona zasługi kobiet w zakresie ich wkładu w pamięć o powstaniach narodowych, w obronę katolicyzmu i polskości, języka polskiego, zaangażowania w rozwój i podtrzymywanie polskiej kultury narodowej w dziejach ${ }^{22}$. Spotkania przedwyborcze organizowane przez Narodową Organizację Kobiet odbywały się wielokrotnie w różnych miastach i miasteczkach województwa białostockiego. W dniu poprzedzającym wybory z 1928 r., wieczorem 3 marca odbyła się w białostockim kościele św. Rocha msza św. w intencji zwycięstwa w wyborach Bloku Katolicko-Narodowego, zamówiona przez działaczki Narodowej Organizacji Kobiet i Stowarzyszenia Pań Miłosierdzia ${ }^{23}$. W miesiącach letnich 1928 r. na łamach „Kuriera Białostockiego ABC” przedstawiono działania polityczne w zakresie rozbudowy politycznych struktur terenowych Narodowej Demokracji. Podczas zjazdu delegatów Rady Okręgowej Związku Ludowo-Narodowego w czerwcu 1928 r., w którym uczestniczyli czołowi przedstawiciele elit endeckich województwa białostockiego, m.in. Witold Staniszkis, Zygmunt Berezowski, Wacław Malinowski (senator), oraz delegaci powiatowi Związku Ludowo-Narodowego, dyskutowano o sprawach polityki krajowej, na temat mobilizacji politycznej w zakresie tzw. rozbudowy terenowych struktur Stronnictwa Narodowego, a także pracy politycznej w organizacjach społecznych. Poruszano również problematykę udziału młodzieży w strukturach partyjnych obozu narodowego ${ }^{24}$. Tematyka dotycząca udziału młodzieży w strukturach zarówno Stronnictwa Narodowego, jak i Obozu Wielkiej Polski przedstawiana była w wielu artykułach „Kuriera Białostockiego ABC „25.

W świetle statystyki na Listę Katolicko-Narodową w wyborach parlamentarnych w $1928 \mathrm{r}$. w powiecie wysokomazowieckim, ,mateczniku wsi postszlacheckich”, głosowało w niektórych gminach nawet 76 proc. mieszkańców, w ostrowskim — do 75 proc. oraz łomżyńskim — do 67 proc. Frekwencja wyborcza na tym obszarze sięgała od 70 proc. do blisko 80 proc. ${ }^{26}$ Należy

\footnotetext{
${ }^{20}$ Archiwum Akt Nowych, Zbiór Dokumentów Obozu Narodowego, sygn. 1, k. 131; APB, UWB, sygn. $37, \mathrm{k} .1-85$.

${ }^{21}$ APB, UWB, sygn. 318, k. 3 i n.; sygn. 40, k. 134 i n.

${ }_{22}$ Zebranie przedwyborcze N.O.K., „Kurier Białostocki ABC” [dalej: „KBABC”], 20 II 1928, nr 50, s. 12.

${ }^{23}$ Narodowa Org. Kobiet. Stow. Pań Miłosierdzia, Msza św. za intencję zwycięstwa, ibidem, 2 III 1928, nr 61, s. 8.

${ }^{24}$ „KBABC”, 25 VI 1928, nr 178, s. 1.

${ }_{25}$ Przykładowo: ibidem, 2 VII 1928, nr 185, s. 1; 12 VII 1928, nr 195, s. 1.

${ }^{26}$ Statystyka wyborów do Sejmu i Senatu odbytych w dniu 4 i 11 marca 1928 roku, Warszawa 1930, s. 6-9.
} 
dodać, że głosy tzw. prawej strony politycznej rozbiły się pomiędzy tę listę a Chrześcijańską Demokrację i Polskie Stronnictwo Ludowe „Piast”.

Wybory do parlamentu z 1930 r. w zasadzie potwierdziły wcześniejszy wysoki wynik ugrupowań związanych z prawicą w części województwa białostockiego. Na Listę Narodową głosowało tam 23 proc. wyborców, natomiast w powiecie ostrowskim -51 proc., w powiecie wysokomazowieckim - ponad 68 proc. (na obszarze gmin wiejskich tego powiatu 77 proc.). Frekwencja wyborcza zbliżona była do tej z 1922 r. $^{27}$ Należy zwrócić uwagę, że zarówno w sprawozdaniach sytuacyjnych wojewody białostockiego, jak i w prasie wybory z 1930 r. nie inicjowały tak intensywnej propagandy jak w 1922 czy 1928 r. Szerzej zakrojone działania propagandowe dotyczyły wyłącznie Bezpartyjnego Bloku Współpracy z Rządem. Struktury partyjne Narodowej Demokracji po wyborach z 1928 r., z nasileniem od 1933 r., ulegały stopniowemu osłabieniu, m.in. w związku z szerokimi działaniami represyjnymi obozu rządowego wobec działaczy struktur narodowych, w tym $\mathrm{z}$ aresztowaniami członków partii czy częstymi konfiskatami nakładów prasy związanej z endecją. Już przed wyborami do parlamentu z 1928 r. zamieszczono w „Kurierze Białostockim ABC” informację o kilku napadach na jego drukarnię, donoszono o konfiskatach nakładu gazety. Przykładowo w jego wydaniu nadzwyczajnym informowano odbiorców na temat konfiskaty części nakładu 26 lutego i całości 28 II 1928 r. ${ }^{28}$ „Białostockie Nowiny Codzienne” w marcu 1933 r. zamieściły komunikat o licznych aresztowaniach w różnych miastach Polski osób związanych z Obozem Wielkiej Polski. Zatrzymany został m.in. Mieczysław Harusewicz, syn Jana Harusewicza z Ostrowi Mazowieckiej, działacza endeckiego jeszcze przed odzyskaniem przez Polskę niepodległości, posła na sejm I kadencji ${ }^{29}$. W maju 1933 r. podjęto próby rozbicia partyjnych struktur Stronnictwa Narodowego i zamknięcia placówek Obozu Wielkiej Polski w województwie białostockim. Prowadzono dochodzenie przeciwko Marianowi Oktawcowi, prezesowi zarządu okręgowych struktur Stronnictwa Narodowego, redaktorowi pisma „Białostockie Nowiny Codzienne”. Sprawa dotycząca aresztowania M. Oktawca znana była krajowym kręgom politycznym ugrupowań narodowych. Podjęto również intensywne działania przeciwko endecji w postaci napadów na placówki Stronnictwa Narodowego w Białymstoku, Łomży, Radziłowie oraz innych miastach i miasteczkach województwa, aresztowano dziesiątki osób związanych z partiami, aktywniejszych członków osadzano w więzieniu, uniemożliwiając im działalność podczas zbliżających się wyborów samorządowych w 1934 r. ${ }^{30}$ Do końca roku 1933 r. struktury partyjne Obozu Wielkiej Polski na obszarze województwa zostały zamknięte, Stronnictwa Narodowego - znacząco osłabione ${ }^{31}$. Od początku 1934 r., z poważnym nasileniem w miesiącach wiosenno-letnich, w związku z przygotowaniami do wyborów samorządowych pro-

\footnotetext{
${ }_{27}$ Na podstawie Statystyki wyborów do Sejmu i Senatu z dnia 16 i 23 listopada 1930 roku, Warszawa 1935, s. XXIV, XXXI, 4.

${ }_{28}$ Bezczelny napad polityczny zbirów. Drugi napad i rabunek nakładu Kurjera Białostockiego ABC, „KBABC”, 28 II 1928, nr 58, s. 1.

${ }_{29}$ Rewizje i aresztowania członków Obozu Wielkiej Polski, „Białostockie Nowiny Codzienne”, 19 III 1933, nr 36, s. 3.

${ }^{30}$ Dochodzenie karne przeciw prezesowi zarzadu Str. Narodowego, „DzB”, 13 V 1933, nr 131, s. 4; Junius, Ruch narodowy w województwie białostockim, „GW”, 9 XII 1933, nr 377, s. 5; Członkowie OWP $w$ więzieniu łomżyńskim, ibidem, 28 III 1933, nr 95, s. 1. W gazecie podano: „W więzieniu w Łomży przebywa 22 aresztowanych, m.in. członkowie wydziału powiatowego w Grajewie, okręgowego OWP w Łomży. W więzieniu przebywa również redaktor pisma OWP w Łomży «Młodzi» — Józef Przybyszewski”.

${ }^{31}$ Mimo delegalizacji Obozu Wielkiej Polski w marcu 1933 r. odnotowywano w województwie funkcjonowanie placówek obozu jeszcze do końca tego roku.
} 
wadzono na szeroką skalę akcję wymierzoną w struktury endeckie, mającą na celu osłabienie Narodowej Demokracji w jej dążeniach do zdobycia mandatów w nadchodzących wyborach. Działania te przejawiały się w unieważnianiu list narodowych, rewizjach w domach działaczy partyjnych, aresztowaniach kandydatów, konfiskatach materiałów propagandowych. Tego rodzaju akcje przeprowadzono m.in. w Białymstoku, Grodnie, Ostrołęce, Zambrowie, Wysokiem Mazowieckiem, Grajewie ${ }^{32}$. W późniejszym czasie, w 1935 i 1936 r., suwalska policja państwowa składała raporty na temat działalności młodzieży szkół średnich oraz młodzieży akademickiej sympatyzującej z Obozem Narodowo-Radykalnym (jednym z wymienianych był Wacław Alchimowicz z gminy Wiżajny w powiecie suwalskim, student Uniwersytetu Stefana Batorego w Wilnie, sympatyzujący z obozem już od czasu edukacji w szkole średniej, kiedy zajmował się kolportażem jego ulotek) ${ }^{33}$.

$\mathrm{Na}$ Suwalszczyźnie zasięg oddziaływania obozu narodowego w porównaniu z rejonem $\mathrm{z}$ dominacją osadnictwa postszlacheckiego był słabszy. Struktury partyjne w porównaniu z terenami przykładowo powiatu wysokomazowieckiego czy łomżyńskiego kształtowały się tam później, jednocześnie wydaje się, że w mniejszym stopniu na Suwalszczyźnie, w porównaniu z zachodnią częścią województwa białostockiego, następowały szeroko rozumiane działania represyjne obozu rządowego, mające na celu uniemożliwienie działalności strukturom endeckim. Służby policyjne dysponowały szczegółowymi informacjami o działalności oddziałów Stronnictwa Narodowego czy zasięgu oddziaływania Obozu Narodowo-Radykalnego na Suwalszczyźnie, jednak poczynania policji ograniczały się głównie do obserwacji i sprawozdań o aktywności opozycyjnych partii politycznych.

Należy jednak podkreślić, że struktury partyjne Stronnictwa Narodowego prowadziły działalność w województwie białostockim do wybuchu drugiej wojny światowej. W $1937 \mathrm{r}$. pod zarząd okręgowy Stronnictwa Narodowego w Łomży podlegały powiaty łomżyński, szczuczyński i ostrołęcki; pod zarząd okręgowy w Białymstoku — powiaty białostocki, sokólski, bielski, wołkowyski, grodzieński, augustowski, suwalski oraz przyłączony z województwa nowogródzkiego Słonimski; pod zarząd okręgowy w Warszawie - wysokomazowiecki i ostrowski. Według sprawozdań policji państwowej na terenie poszczególnych powiatów działalność polityczną prowadziło od kilkunastu do kilkudziesięciu (w takich powiatach jak wysokomazowiecki, łomżyński czy ostrowski) kół ${ }^{34}$. Rok później w policyjnych materiałach sprawozdawczych odnotowano, że Stronnictwo Narodowe miało członków w Suwałkach, Sejnach oraz w gminach Suwalszczyzny (takich jak Giby, Jeleniewo, Krasnopol, Koniecbór, Kuków i Zaboryszki), łącznie skupiając blisko sześciuset członków ${ }^{35}$.

\section{Elity Narodowej Demokracji — próba charakterystyki na wybranych przykładach}

W strukturach politycznych Narodowej Demokracji elitę stanowili parlamentarzyści, zwłaszcza posłowie (ze szczególnym uwzględnieniem posłów kilku kadencji), oraz ci, którzy byli liderami w strukturach głównych (centralnych), kierowniczych obozu narodowego.

\footnotetext{
32 Zżycia Biategostoku „GW”, 4 II 1934, nr 36, s. 6; Interpelanci, Przeciw represjom politycznym w powiecie ostrolęckim, ibidem, 9 II 1934, nr 41, s. 5; Z całego kraju, ibidem, 27 V 1934, nr 155, s. 9; Kurp, Wybory w Ostrolęce, ibidem, 3 VI 1934, nr 163, s. 9.

${ }_{33}$ Państwowe Archiwum Obwodu Grodzieńskiego w Grodnie [dalej: PAOGG], Komenda Powiatowa Policji Państwowej Powiatu Suwalskiego, f. 209 [dalej: KPPPS], sygn. 25, k. 152-155.

${ }_{34}$ Archiwum Państwowe w Suwałkach [dalej: APS], Policja Państwowa Powiatu Suwalskiego [dalej: PPPS], sygn. 98, k. 37-84.

${ }^{35}$ APS, Komenda Powiatowa Policji Państwowej w Suwałkach, sygn. 106, k. 18.
} 
Na czoło elit o zasięgu ponadregionalnym wysuwali się wymieniani Kazimierz Lutosławski, Jan Załuska, Bohdan Winiarski, Zygmunt Berezowski, Witold Staniszkis. Ich zaangażowanie polityczne było ogólnokrajowe, a częściowo sięgało również przestrzeni międzynarodowej ${ }^{36}$. Wśród mieszkańców opisywanego regionu pozycja polityczna tych elit budowana była m.in. w tzw. kontakcie bezpośrednim ze społeczeństwem, głównie podczas spotkań na wiecach. Propagowali oni także poglądy ideowopolityczne w tekstach publicystycznych. Stałe rubryki, często na pierwszych stronach periodyków o narodowym zabarwieniu ideowym, przykładowo w „Gazecie Warszawskiej”, mieli m.in. ks. Kazimierz Lutosławski, Bohdan Winiarski czy Zygmunt Berezowski ${ }^{37}$.

Kazimierz Lutosławski, poseł Sejmu Ustawodawczego, był niewątpliwym autorytetem pośród innych parlamentarzystów reprezentujących po 1919 r. Związek Ludowo-Narodowy. Podczas bezpośrednich spotkań z mieszkańcami łomżyńskiego czy ziem sąsiednich przekazywał informacje na temat prac poselskich, działań rządu, polityki wewnętrznej i międzynarodowej państwa polskiego, pouczał na temat bieżących problemów kraju, wysuwał prognozy polityczne na przyszłość, występował jako propagator wychowania młodzieży w duchu narodowym. K. Lutosławski zaangażował się w tworzenie wielu oddziałów Związku LudowoNarodowego na obszarze nie tylko województwa białostockiego. Przykładowo, uczestniczył także w powołaniu Związku Ludowo-Narodowego w Wilnie ${ }^{38}$. Wyrazisty język przekazu, nasycony ostrymi sformułowaniami również o charakterze antyżydowskim, przysparzał mu zarówno zwolenników, jak i przeciwników. Pozycję polityczną w Sejmie i w regionalnym środowisku endeckim wzmacniało jego wszechstronne wykształcenie, zdobyte poza granicami Polski, a także fakt, że pochodził z rodziny związanej nie tylko politycznie, ale i towarzysko z głównymi twórcami polityczno-ideowymi Narodowej Demokracjii ${ }^{39}$.

W przeciwieństwie do Kazimierza działalność jego brata, Jana Lutosławskiego, w zasadzie nie dotyczyła tzw. pracy terenowej, wpływała natomiast na kształtowanie i utrwalanie poglądów politycznych elit regionalnych ze środowiska ziemiańskiego. Jan Lutosławski uzasadniał w artykułach prasowych, głównie na łamach „Gazety Rolniczej”, rolę i znaczenie ziemian w polskiej gospodarce narodowej. Według niego to polskie ziemiaństwo miało być „warstwą polityczną” kreującą rzeczywistość społeczną i gospodarczą niepodległej Polski. Poddawał również krytycznym ocenom zaangażowanie części polskich ziemian w tworzenie struktur politycznych, brak umiejętności dostosowania się do zmieniającej po 1918 r. sytuacji społecznej, gospodarczej i politycznej. Nie szczędził części ziemiaństwa uwag także na temat jego zacofania, które skutkowało pomijaniem interesów tej warstwy w tworzonej i zmieniającej się rzeczywistości społeczno-politycznej odrodzonej Polski ${ }^{40}$. Mimo że propagował powołanie, na wzór angielski, rolniczego stronnictwa politycznego, które jak żadna inna partia zadbać miałoby o interes

\footnotetext{
${ }^{36}$ Biblioteka UAM w Poznaniu, Gabinet Rękopisów, sygn. rkps 3093/1, Jerzy Drobnik, Diariusz, Poznań, 7XII 1924-15XI 1931, k. 24, 215.

${ }^{37}$ M. Dajnowicz, Stosunki zewnętrzne i polityka wewnętrzna państwa polskiego w opiniach wybranych publicystów ,,Gazety Warszawskiej”, w: Prasa Narodowej Demokracji. Publicyści, t. III, red. E. Maj, A. Dawidowicz, Lublin 2012, s. 195-210.

${ }^{38}$ Obecny, Wiec, „GL”, 3 XII 1923, nr 37, s. 2; Zjazd 3500 delegatów z catej Polski Zwiąku LudowoNarodowego, „DzW”, 15 V 1919, nr 22, s. 1.

${ }^{39}$ Szerzej M. Dajnowicz, Ksiadz Kazimierz Lutosławski - wychowawca, ideolog i działacz polityczny, w: Kościót-religia-myśl katolicka. Studia i szkice ofiarowane Profesorowi Antoniemu Mieczkowskiemu z okazji 70 urodzin, red. E. Maj, J. Sanecka-Tyczyńska, M. Wichmanowski, A. Wójcik, Lublin 2012, s. 61-70. Z rodziną Lutosławskich przyjaźnił Roman Dmowski, w ich majątku rodzinnym w Drozdowie koło Łomży bywał w końcu XIX w. również Zygmunt Balicki.

${ }^{40}$ W. Mich, Ideologia polskiego ziemiaństwa 1918-1939, Lublin 2000, s. 266, 291, 292.
} 
warstw rolniczych, należy podkreślić, że pozostawał także wiernym zwolennikiem ideologii narodowych demokratów. Popierał angażowanie się ziemian w działalność Związku LudowoNarodowego, apelował do wstępowania w szeregi Stronnictwa Chrześcijańsko-Narodowego ${ }^{41}$.

Wydaje się, że w porównaniu z J. Lutosławskim większe zaangażowanie na rzecz umacniania wpływów Narodowej Demokracji na tzw. terenie Białostocczyzny w postaci wsparcia organizacyjnego w tworzeniu struktur terenowych wykazywał Bohdan Winiarski. W sprawozdaniach sytuacyjnych wojewody białostockiego wymieniano B. Winiarskiego jako uczestnika wielu wieców Stronnictwa Narodowego w województwie białostockim w 1928 r. Jednak niekwestionowanym organizatorem tzw. terenowej pracy politycznej, nastawionej na budowanie struktur Stronnictwa Narodowego na Białostocczyźnie, pozostawał Witold Staniszkis. Można przyjąć, że był on głównym inicjatorem oraz częściowo wykonawcą tworzenia endeckich placówek partyjnych na omawianym terenie między 1926 a 1928 r. Do posła W. Staniszkisa, także w wystąpieniach podczas organizowanych przez niego wieców politycznych, dołączali inni posłowie, tacy jak wymieniani Jan Załuska, Jan Harusewicz, Zygmunt Berezowski, Zygmunt Kadłubowski ${ }^{42}$.

Mimo że posłowie stanowili elitę w środowisku politycznym, niejednokrotnie większym zaufaniem społecznym na terenie powiatów czy gmin cieszyli się działacze lokalni. Pośród przywódców struktur endeckich na poziomie regionu wymienić należy przykładowo instruktora okręgowego sekretariatu Stronnictwa Narodowego w Łomży Zygmunta Szczepańskiego. W sprawozdaniu sytuacyjnym z lipca 1928 r. wojewoda białostocki zanotował, że „Zygmunt Szczepański objechał prawie wszystkie gminy w powiecie łomżyńskim oraz odbył szereg konferencji z księżmi i mężami zaufania SN. Na wniosek Szczepańskiego postanowiono zorganizować w każdej parafii koło parafialne związku i zająć się werbunkiem nowych członków drogą zbierania zapisów na listach. Akcja werbunku spoczywa w rękach księży, którzy przyjmują zapisy nowych członków. Aktualnie werbunek odbywa się w parafiach lubotyńskiej, szumowskiej i szczepankowskiej" ${ }^{43}$. W innym sprawozdaniu sytuacyjnym wspomina się o działalności politycznej posła, ziemianina Stanisława Włodka, wybranego jesienią 1928 r. na prezesa koła Stronnictwa Narodowego w powiecie Wysokie Mazowieckie. Na to zebranie wyborcze przybył poseł Zygmunt Berezowski, który zabrał głos, przekonując uczestników o zasługach politycznych S. Włodka ${ }^{44}$. W powiecie łomżyńskim autorytetem politycznym w społeczności drobnoszlacheckiej cieszył się Konstanty Długoborski, rolnik drobnoszlachecki z Długoborza położonego koło Zambrowa, członek rady gminy, kandydat na posła do Sejmu Ustawodawczego oraz kandydat na liście okręgowej w wyborach do Senatu w 1922 r. Szczególną aktywność wykazywał on podczas wieców politycznych na terenie powiatu łomżyńskiego, włączył się też w akcję poparcia Chrześcijańskiego Związku Jedności Narodowej. Publikował dosyć regularnie w „Gazecie Łomżyńskiej”, gdzie popularyzował program polityczny Narodowej Demokracji ${ }^{45}$.

Wydaje się, że zwłaszcza w okresie późniejszym, po 1928 r., w wyniku osłabienia przedstawicielstwa endeckiego $\mathrm{w}$ parlamencie widziano zagrożenie $\mathrm{w}$ budowaniu rzeczywistoś-

\footnotetext{
${ }^{41}$ Zob. M. Dajnowicz, Zachodnioeuropejski wzorzec gospodarczy a rozwój polskiego rolnictwa w świetle wybranej publicystyki Jana Lutosławskiego, ,Studia z Historii Społeczno-Gospodarczej XIX i XX wieku", t. VIII, red. W. Puś, J. Kita, Łódź 2010, s. 185-194.

${ }^{42}$ APB, UWB, sygn. 44, k. 92-159; sygn. 45, k. 50, 128-129; sygn. 37, k. 4-35.

${ }^{43}$ Ibidem, sygn. 44, k. 82-82a, 117.

${ }^{44}$ Ibidem, sygn. 45, k. 52-52a.

${ }^{45}$ K. Długoborski, Z wiecu w Zambrowie z d. 30 listopada, „GE”, 13 XII 1919, nr 6, s. 3; idem, Za kim głosować, ibidem, 9 IX 1922, nr 35, s. 2, 3.
} 
ci społecznej zgodnej z porządkiem piłsudczykowskim właśnie w politycznych strukturach opozycyjnych powiatowych czy gminnych oraz w organizacjach społecznych, w których działalność prowadzili członkowie i współpracownicy Stronnictwa Narodowego. Świadczyły o tym szczegółowe raporty policji państwowej na temat działalności grup i pojedynczych osób związanych ze Stronnictwem Narodowym czy Obozem Wielkiej Polski.

Autorytetem w lokalnej suwalskiej społeczności mógł być Adam Ptaszyński, członek Stronnictwa Narodowego, lekarz, radny miejski, o którym policja państwowa powiatu suwalskiego pisała w 1935 r., że ,posiada wpływy wśród inteligencji, do państwa usposobiony przychylnie, do rządu wrogo" ", czy wymieniany wcześniej, również w cytowanym sprawozdaniu, adwokat Zygmunt Kadłubowski, ,,posiadający wpływy wśród rolników, robotników i biedniejszej inteligencji" ${ }^{47}$. W powiecie suwalskim działalność polityczną prowadzili m.in. Stefan Perkosz, prezes zarządu powiatowego Stronnictwa Narodowego, i Józef Kuncewicz, gospodarz rolny, prezes zarządu koła sejneńskiego, który — jak notowano w raportach — aktywnie „uprawia agitację wśród wiejskiej ludności na rzecz Stronnictwa Narodowego i sieje nienawiść do obecnego rządu"48. W 1936 r. policja państwowa w powiecie suwalskim zwracała uwagę na szczególnie aktywną działalność antyrządową Mieczysława Jaroszewicza, działacza Stronnictwa Narodowego w Sejnach. Wspominano także o jego przynależności do Obozu Wielkiej Polski oraz w późniejszym czasie do Obozu Narodowo-Radykalnego. Jego aktywna działalność w partyjnych strukturach endeckich przerwana została jedynie na kilka miesięcy w 1934 r., kiedy między czerwcem a listopadem tego roku został zamknięty w Berezie Kartuskiej ${ }^{49}$.

Młode pokolenie elit związanych z obozem narodowym zaangażowanie polityczne wyraźnie okazywało już od około 1926 r. Zwartą organizacją skupiającą młodzież akademicką była Młodzież Wszechpolska. Koła tej organizacji powstawały w różnych miastach akademickich. Młodzież z Białostocczyzny uczestniczyła przykładowo w pracach koła warszawskiego. Z Młodzieżą Wszechpolską współpracował także wymieniany Bohdan Winiarski. Związki Akademickie tej organizacji szczególną aktywność przejawiały w okresie przygotowań do wyborów w 1928 r. ${ }^{50} \mathrm{~W}$ wielu przypadkach młodzież zasilająca Obóz Wielkiej Polski czy Obóz Narodowo-Radykalny związana była również ze Stronnictwem Narodowym. W sprawozdaniu policji państwowej dotyczącym powiatu suwalskiego wymienia się w 1935 r. przykładowo Adama Ptaszyńskiego z Suwałk, sekretarza Stronnictwa Narodowego, podejrzanego również o kolportowanie z Wilna ulotek Obozu Narodowo-Radykalnego ${ }^{51}$.

Należy także wspomnieć o roli kobiet w endeckich strukturach elit politycznych. Poprzez działalność w Narodowej Organizacji Kobiet czy Kole Ziemianek wzmacniały wpływy Narodowej Demokracji na danym terenie. Przykładem przywódczyni działającej w politycznych strukturach endeckich może być posłanka Ewelina Pepłowska, swoją pracą wzmacniająca z jednej strony Narodową Organizację Kobiet, z drugiej zaś zaangażowana w działania na rzecz powstawania placówek Stronnictwa Narodowego w omawianym województwie. E. Pepłowska publikowała także dosyć regularnie na łamach „,Gazety Warszawskiej”, prezentując opinie na temat wychowania narodowego Polaków, znaczenia prywatnej własności w rozwoju gospodarczym Polski czy wpływu młodzieży na przy-

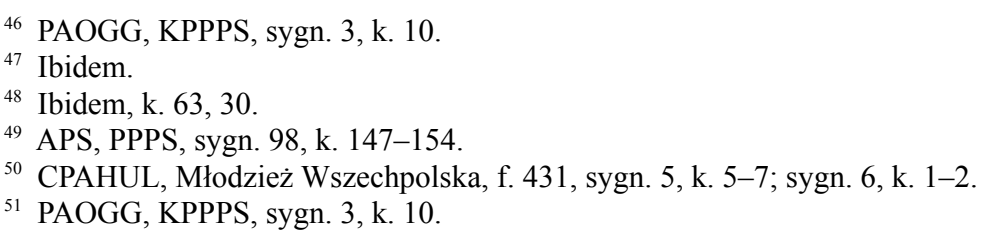


szłość państwa polskiego ${ }^{52}$. Do elit kobiecych związanych z Narodową Demokracją należała w Suwałkach Julia Kunc, przewodnicząca Narodowej Organizacji Kobiet działającej tam od 1925 r., na przełomie lat dwudziestych i trzydziestych organizatorka biura pośrednictwa pracy w tym mieście oraz kursów zawodowych dla kobiet czy świetlicy dla dzieci z ubogich polskich rodzin ${ }^{53}$.

Autorytetem wśród działaczy i sympatyków obozu narodowego cieszyli się częściowo wymieniani publicyści i redaktorzy gazet związanych z narodowym kierunkiem ideowym. Stopień profesjonalizacji pracy tych publicystów należy ocenić wysoko, co korelowało z dobrym merytorycznym przygotowaniem, odzwierciedlonym w podejmowanej problematyce. Wśród nich dominowali przedstawiciele elit kierowniczych obozu narodowego, w tym także redaktorzy i dziennikarze odpowiedzialni za kierunek ideowopolityczny gazety. Przykładem mogą być Kazimierz Lutosławski, Zygmunt Berezowski czy Bohdan Winiarski ${ }^{54}$. Na poziomie regionu w pracy publicystyczno-dziennikarskiej wyróżniał się Benedykt Filipowicz, redaktor naczelny „Kuriera Białostockiego ABC”, prezentujący na łamach gazety problematykę koncepcji budowania Polski jako silnego państwa narodowego, pronarodowych zasad tworzenia ładu społecznego czy politycznego w odrodzonej państwowości polskiej ${ }^{55}$.

\section{Uwagi podsumowujące}

Narodowa Demokracja w zachodniej części województwa białostockiego w okresie II Rzeczypospolitej cieszyła się największym poparciem ludności, bardzo dużym także po 1928 r. Związane to było z oddziaływaniem czy pracą polityczną elit, przywódców politycznych środowisk endeckich, w tym reprezentantów partii politycznych. Były to osoby sprawujące rzeczywiste kierownictwo (przywództwo) w partiach i organizacjach związanych z działalnością partyjną. Tzw. treść polityczną przekazywali oni w słowie pisanym i mówionym. Popularyzując program Narodowej Demokracji, prezentowali poglądy na kwestie społeczne czy gospodarcze, sprawy wewnętrzne Polski czy z zakresu wydarzeń międzynarodowych. Część elit wchodząca również w skład politycznych struktur krajowych w wyrażanych poglądach na łamach gazet czy w tzw. przekazie wiecowym eksponowała znajomość różnorodnych zagadnień z zakresu polityki państwa polskiego. W znaczącej części przekaz polityczny dotyczył także spraw regionu, z którym byli związani.

Elity polityczne Narodowej Demokracji związane z województwem białostockim to grupa zróżnicowana. Znani i podziwiani przez mieszkańców nie tylko łomżyńskiego byli przedstawiciele rodziny Lutosławskich. Jan Lutosławski prezentował poglądy polityczne w publicystyce, skierowane głównie do warstwy ziemiańskiej. Przykładem polityków nastawionych na wykonywanie zadań związanych z rozbudową politycznych struktur organizacyjnych, w tym partyjnych, byli Kazimierz Lutosławski oraz przede wszystkim w okresie późniejszym Witold Staniszkis. Część przedstawicieli elit (przykładem Jan Załuska, Bohdan Winiarski), choć w mniejszym stopniu niż wymieniani K. Lutosławski czy W. Staniszkis, swoim autorytetem oraz zaangażowaniem wzmacniała także działaczy politycznych z poziomu lokal-

\footnotetext{
52 E. Pepłowska, Na szlaku Chudego Wilka, „GW”, 25 XI 1932, nr 259, s. 4; eadem, Własność miejska a kryzys, ibidem, 13 XII 1932, nr 381, s. 7; E. P., Czcigodna placówka, ibidem, 9 XI 1933, nr 343, s. 2. ${ }_{53}$ PAOGG, Starostwo Powiatowe Suwalskie, f. 208, k. 17a.

${ }_{54}$ M. Dajnowicz, Stosunki zewnętrzne i polityka wewnętrzna państwa polskiego w opiniach wybranych publicystów...

${ }_{55}$ B. F., Potrzeba nowego Sejmu, „Kurier Białostocki” [dalej: „KB”], 18 IX 1921, nr 2, s. 1; B. F., Krótki żywot, ibidem, 22 IX 1921, nr 5, s. 1; idem, Niezdrowe agitacje, ibidem, 12 VIII 1921, nr 70, s. 1.
} 
nego. W latach trzydziestych, kiedy uwidoczniły się w elitach zmiany pokoleniowe, wśród młodego pokolenia Obozu Wielkiej Polski czy Obozu Narodowo-Radykalnego autorytetem pozostawał Zygmunt Berezowski.

Wydaje się, że na prowincji, na obszarach wiejskich oddalonych od miast, w tzw. terenie województwa białostockiego poglądy ideowe wygłaszane czy pisane przez przywódców centralnych struktur narodowych miały często znaczenie drugorzędne w porównaniu z działaniami liderów z poziomu lokalnego. Działacze lokalni cieszyli się autorytetem z powodu sprawności organizacyjnej; zdobycie zaufania społecznego w miasteczkach i gminach ułatwiało pochodzenie ze środowisk, w których prowadzili pracę polityczną. Dla utrwalania wpływów politycznych Narodowej Demokracji na omawianym obszarze bardzo ważna była praca lokalnych przywódców struktur politycznych. W polityce państwowej po $1926 \mathrm{r}$. starano się, poprzez rozbudowę m.in. systemu policyjnego, z jednej strony szczegółowo rozpoznawać lokalne inicjatywy polityczne endecji, z drugiej zaś władze państwowe podjęły skuteczne działania nastawione właśnie na uniemożliwienie działalności politycznej w oddziałach partyjnych gminnych czy powiatowych. Praca terenowa takich działaczy struktur narodowych jak Zygmunt Kadłubowski z Suwałk czy Stanisław Włodek i Zygmunt Szczepański, związanych z łomżyńskim, przynosiła efekty od 1930 r. w postaci sukcesów endecji w działających, mimo prób ich rozbicia, lokalnych strukturach politycznych. Wśród czynników stymulujących wpływy polityczne Narodowej Demokracji, zwłaszcza w zachodniej części województwa, wymienić należy także strukturę społeczną ludności. Mieszkańcy wsi postszlacheckich wykazywali „stałe” sympatie do obozu narodowego. Ludność z powiatów wysokomazowieckiego czy łomżyńskiego głosowała na ugrupowania endeckie podczas wyborów do Sejmu w 1919 r., jak i w czasie późniejszym, w wyborach do parlamentu w 1922, 1928 czy 1930 r., oraz w głosowaniu na poziomie samorządowym. Sympatie polityczne tej ludności przejawiały się w jej przynależności do partii i organizacji związanych z Narodową Demokracją. Wpływy Narodowej Demokracji w województwie białostockim umacniał zaangażowany politycznie kler katolicki. Zaangażowanie polityczne (zwłaszcza przed wyborami) na rzecz stronnictw endeckich czy chadecji, prezentowane także przez wyższych hierarchów kościelnych, sprzyjało utrwalaniu wpływów politycznych stronnictw prawicy na omawianym terytorium.

\section{The Impact of the National Democracy in the Voivodeship of Białystok. The Elites and Their Role in the Creation of the Political Structures of the National Democracy (1919-1939)}

At the time of the Second Republic the National Democracy (ND) enjoyed considerable support across the voivodeship of Białystok. The local population, in particular the inhabitants of former gentry villages, supported the National Democracy during elections to the Seym $(1919,1922,1928$ and 1930) and self-governments. The political sympathies of this particular group were reflected in its affiliation to parties and organisations associated with the National Democracy. The influence exerted by the national democrats in the titular voivodeship was consolidated by the politically engaged Catholic clergy. The majority of the National Democratic elites engrossed in political activity in the voivodeship in question commenced their political involvement before 1918 . They comprised a formalised group belonging to ND party structures and social organisations politically connected with the National Democracy. The greatest authority and political impact belonged to members of parliament (particularly those in office for several terms, such as Kazimierz Lutosławski, Witold Staniszkis, Jan Załuska or Jan Harusewicz). Work conducted by local leaders of political structures was also of great importance for the implementation of the political bearing of the National Democracy in the region under discussion. 